\title{
ADELBERT VON CHAMISSO E O NARCISISMO PRIMÁRIO*
}

Sabine Parmentier

Psicanalista, membro do Espace

Analytique, Paris

Tradução

Pedro Henrique

Bernardes Rondon

RESUMO: Adelbert von Chamisso foi um escritor e poeta de língua alemã, nascido em família aristocrática francesa emigrada para aAlemanha em 1792. Este artigo, examinando o conto “L'étrange histoire de Peter Schlemihl", primeiro trabal ho publicado por Chamisso, aponta os aspectos autobiográficos dessa obra que antecipa a vida de seu autor até na exatidão das minúcias. 0 artigo mostra como a sublimação artística permitiu que o escritor encontrasse para si mesmo um caminho pelo trabalho científico e pela criação literária, e indica que essa espécie de "aceitação intelectual" do recalcado poderia ser vista como equivalente a um resultado de tratamento psicanalítico.

Palavras-chave: Romantismo alemão, narcisismo primário, sublimação, ideal do Eu.

ABSTRACT: Adelbert von Chamisso and the primary narcissism. Chamisso was a German writer and poet born in an aristocratic French family emigrated to Germany in 1792. This paper, inquiring into Chamisso's tale "L'étrange histoire de Peter Schlemihl", his first issued writing, points to its autobiographical features that anticipate the life of its author even in its precise details. This paper shows how artistic sublimation allowed the writer to succeed in finding for himself a path towards scientific work and literary creation, and emphasizes that this kind of "intellectual acceptation" of the repressed could be seen as equivalent to the result of a psychoanalysis treatment.

Keywords: German romanticism, primary narcissism , sublimation, Ego ideal.

*Texto traduzido do original francês "Adelbert von Chamisso et le narcissisme primaire", inédito. 
$\mathrm{N}$ a rica história do romantismo alemão, há muitos autores cuja vida e obra se imbricam de modo estreito; cuja vida anuncia e esclarece a obra como a anamnese esclarece o sintoma, uma vez que o romantismo é em essência autobiográfico. Mas são poucos aqueles cuja obra antecipa a vida e a prefigura até na precisão das minúcias. Este é o caso de Adelbert von Chamisso e de seu conto "Peter Schlemihls wundersame Geschichte", relato estranhamente autobiográfico.

A tradução do título tem variado muito em francês e a escolhida pelo próprio Chamisso, em 1821, era apenas "Peter Schlemihl"; em 1838, o texto ganhou a versão "A maravilhosa história de Peter Schlemihl". A edição póstuma de 1934 - houve 33 edições até hoje - se intitula "A história extraordinária de Peter Schlemihl", por referência às "Histórias extraordinárias" de Edgar Allan Poe na tradução de Charles Baudelaire, e, afinal, a edição mais recente, de 1992, intitulada "A estranha história de Peter Schlemihl".

O surgimento desse conto - primeiro trabalho escrito publicado por Chamisso - trouxe-lhe uma celebridade que se espalhou com rapidez incrível. Numa carta escrita a seu amigo Louis de La Foye em 1818, quatro anos após a publicação de Peter Schlemihl, Chamisso conta como ele próprio encontrou esse livrinho, por ocasião de sua viagem de três anos em volta do mundo, em Copenhague e no Cabo da Boa Esperança: "nas bibliotecas que emprestam livros a regra é que ele seja roubado" (LAHNSTEIN, 1987, p. 143). A Bibliotheca Schlemihliana assinala em cem anos - entre 1814, data da primeira edição estabelecida por Friedrich de La Motte Fouqué, e 1919 - , e sem contar as reedições sem modificações: 80 edições na Alemanha, 14 na Inglaterra e nos Estados Unidos, dez na França, quatro na Rússia. A história tinha sido traduzida em 12 línguas, algumas durante a vida de Chamisso. E por que tal celebridade? Diferentes interpretações foram dadas à perda da sombra, mas os críticos estão de acordo quanto a dizer que esse relato propõe "o problema da identidade individual e da diferença em relação aos outros semelhantes" (LORTHOLARY, 1992, p. 21), exatamente num período da história européia em que to das as vel has identidades se estilhaçavam. Também nisso a história é autobiográfica.

Adelbert von Chamisso tinha o nome francês Louis Charles Adélaïde de Chamissot de Boncourt, era o sexto dos sete filhos do conde Chamissot de Boncourt. Não se sabe exatamente em que ano nasceu, mas sabe-se que foi no castelo de Boncourt, perto de Sainte Menehould, na Lorraine. Seu batizado católico data de 31 de janeiro de 1781. Uma vez que a situação dos aristocratas tornava-se cada vez mais precária, a família Chamissot deixou Boncourt em maio de 1792, e fugiu para o Norte. Em janeiro de 1793, o mobiliário foi vendido em leilão, e o próprio castelo foi entregue aos demolidores. Tudo foi vendido, portas, janelas, as vigas, o telhado, e até as pedras das paredes, que serviram para 
construir ou para reformar construções existentes. Bem mais tarde, Chamisso escreveu um poema que gerações de estudantes alemães decoraram, e que tem por título "Das Schloss Boncourt":

"Sonho com a época de minha infância

E balanço a cabeça encanecida.

Por que me obsedais, imagens

Que eu acreditava estivessem esquecidas há muito tempo?

Do meio da mata cheia de sombra

Surge ao sol um castelo:

Conheço suas torres, suas ameias,

A ponte de pedra, a grande porta.

Eis a esfinge perto do poço,

Lá longe a figueira que enverdece.

Lá, por trás dessas janelas,

Sonhei meu primeiro sonho.

$[\ldots]$

É assim, castelo de meus pais,

Que vives hoje no meu coração

Agora que de ti só resta

U ma terra onde 0 arado labora.

Eu te abençôo, terra querida,

Eu te bendigo sem amargura,

$E$ bendigo em dobro aquele

Que labuta nesses locais onde exististe.

Mas eu, eu quero me apoderar novamente,

Eu irei embora, com a lira nas mãos,

Percorrendo terras longínquas,

Cantando de país em país."

Esse castelo Ihe aparece em sonhos e nos devaneios, e com perturbadora precisão de minúcias. Trinta anos após seu desaparecimento, ele escreve à irmã: 
"Recentemente desenhei na minha memória o jardim, até a mínima curva da aléia mais afastada, até a menor moita, e a força de minha imaginação era tão viva que representava para mim com a máxima precisão todos esses pormenores intactos. Eu estava fora de mim!"

E em 1837, um ano antes de sua morte, ele escreve a Louis de La Foye: "Eu não paro de sonhar com o castelo de Boncourt" (LAHNSTEIN, 1987, p.15). Aliás, esse poema inspirou ao rei Frederico Guilherme IV uma carta dirigida a Chamisso, considerada "uma das cartas mais bonitas que um príncipe alemão já escreveu" (idem, p.14).

“Onde foi que o senhor aprendeu o alemão goethiano que escreve? Sem dúvida há mais de um francês cujo coração se abriu à Alemanha e aos alemães, mas nunca nenhum igualou ou mesmo superou os melhores em seu idioma (...) Eu gostaria de ouvir seu 'Castelo de Boncourt' cantado: basta lê-lo que as lágrimas brotam nos ol hos de cada um, e involuntariamente nos vemos dando ao senhor a bênção que o senhor dá àquele que trabalha o solo precioso!" (RIEGEL, 1950, p. 34)

Depois de uma passagem por Flandres e pela Holanda, e em seguida pela Alemanha em Düsseldorf, Wurtzburg e Bayreuth, a família Chamisso se estabelece em Berlim, onde os filhos mais velhos entram como miniaturistas na fábrica real de porcelanas, para sustentar a família - e o jovem Adelbert, tendo mudado o prenome, entra como pajem a serviço da Rainha Frederica Luísa. A rainha, cuidadosa quanto à educação de seus pajens, fê-lo entrar no liceu francês de Berlim, onde Chamisso teve seus primeiros contatos com aquilo que se chamava a "colônia", isto é, os protestantes franceses que se refugiaram em Berlim após a revogação do Edito de Nantes, em 1685. Naquela ocasião, os cerca de dez mil habitantes originais de Berlim acolheram mais de cinco mil franceses, pessoas austeras, trabalhadoras, sérias. Théodore Fontane, que provinha do mesmo meio, descreve da maneira seguinte, em 1888, aquele momento, em "Die Marker und die Berliner":

Aqueles que vinham então da França não eram parisienses, eram puritanos, austeros, sérios, cheios de melindres quanto à honra - o que em sua maioria continuaram sendo até hoje. Eles exerceram profunda influência não apenas sobre o modo de vida, que se tornou mais refinado, mas também sobre as profissões..." (FONTANE, 1977, p.143)

A colônia era um ambiente muito fechado. Chamisso aí fez amizades que conservou até o fim da vida, como com Friedrich de La Motte Fouqué. Foi aí que 
ele tomou conhecimento da literatura alemã contemporânea, Klopstock, Schiller, com a filosofia de Moses Mendelssohn. Estes anos fizeram com que o católico de origem nunca mais se sentisse à vontade entre seus pares.

Saindo do liceu, uma questão se antepôs ao jovem Adelbert, questão inaudita que até então ninguém em sua família tinha tido que enfrentar: a questão do seu futuro. De fato, embora já houvesse muito tempo que a nobreza perdera qualquer papel político real, e embora as Luzes e a burguesia tivessem penetrado mesmo intelectualmente nessa nobreza - em especial nas cidades - a nobreza que vivia em suas terras tinha conservado firmemente as tradições que faziam com que um indivíduo que fizesse parte dela não tivesse nenhum papel a representar como pessoa particular que tivesse um destino também particular. 0 indivíduo era apenas um "representante de seu estado (...) garantia da imortalidade da raça". Quanto ao direito que esse indivíduo pudesse reivindicar, o direito a uma vida pessoal, quanto a sua pretensão a ser feliz - é aí que, segundo um contemporâneo, Ludwig August von der Marwitz, se situa "essa premissa indefensável" do mundo moderno, de onde provêm "todas essas maquinações que desde então puseram a Europa inteira de pernas para o ar" (ARENDT, 1986, p.55). Tal "representante" da nobreza tem sua existência inteiramente determinada pelo nascimento: tudo o que se exige dele é que seja "um membro de sua família" e, nessa qualidade, em toda parte ele estará no mesmo nível, acolhido, respeitado.

U ma vez que a questão de seu destino pessoal tinha se colocado para ele em vista das circunstâncias, Chamisso entrou então para o exército prussiano em 1798, como alferes no Regimento de Infantaria de Götze, à época aquartelado em Berlim. Serviu durante oito anos, e foi aí que aprendeu o alemão. Perto do final de sua vida, numa carta à irmã - toda sua família tinha voltado para a França em 1801 - ele vai escrever que para ele o alemão foi sempre a língua da escrita, enquanto o francês - que ele escrevia mal - continuava sendo a língua em que pensava, cantava e sonhava.

Enquanto estava aquartelado em Berlim, Chamisso começou a freqüentar os salões literários dos judeus de Berlim, especialmente o mais famoso de todos, 0 de Rahel Lewin, futura mulher de seu amigo August Varnhagen.

Conviria lembrar a importância dos salões dos judeus de Berlim na formação do romantismo alemão e, ainda mais, na formação do espírito moderno. Talvez dois elementos permitam iluminar a complexidade desse fenômeno: 0 reconhecimento completo dos judeus como cidadãos eirmãos - devido àquilo que tem sido chamado de "fredericanismo", mistura de "Iluminismo", de escolha pessoal devida a um monarca esclarecido, e de movimento dos espíritos que encontrou as condições de expressar-se, como se vê em Nathan le sage de Lessing; em todo caso, essa mistura resultou na liberação dos judeus e na abertura 
dos guetos, fenômeno que se produziu pela primeira vez e da maneira mais clara na Prússia. 0 segundo elemento é conseqüência disso: trata-se da decisão diante da qual cada judeu se encontrava, e que voltamos a encontrar cem anos depois até no círculo das pessoas que andavam à volta de Freud, a decisão de ou situar a si mesmo em posição de igualdade com os alemães, correndo 0 risco de se incorporar numa tradição milenar, ou permanecer fiel à fé de seus pais. Quem imprimia seu nome nesse caminho da emancipação pessoal dos judeus era, ele próprio, um judeu fiel à fé e versado na tradição rabínica mas quatro dos seis filhos que teve se converteram. Trata-se do filósofo alemão Moses Mendelssohn que, o primeiro dentre os judeus da Alemanha, utilizou 0 alto alemão tanto como língua de uso cotidiano quanto como língua da cultura. Até então os judeus utilizavam o hebraico para os estudos eruditos tradicionais e o iídiche para os assuntos da vida diária. Por seus trabalhos e por seu exemplo, não é exagero dizer que Moses Mendelssohn "fez daqueles que antes eram judeus na Alemanha, verdadeiros judeus alemães" (LAHNSTEIN, 1987, p.46). Na ocasião de sua morte, as cortes dos príncipes da Europa prantearam "a perda irreparável que Berlim e o mundo inteiro acabavam de sofrer", conforme Elise von der Recke, uma aristocrata do Báltico, ao escrever à amiga duquesa de Curlande.

É possível ter uma idéia daquilo que Moses Mendelssohn realizou na consciência dos alemães cultos, graças ao prólogo em versos que um dramaturgo da época escreveu para a representação do "Mercador de Veneza", de Shakespeare, em 1788:

"No momento, o vivo espírito berlinense começa a ter estima

Mais elevada pelos correligionários do sábio Mendelssohn

No momento, nesse povo cujos profetas e cujas leis veneramos,

Vemos homens versados nas ciências e nas artes."

A questão de emancipação, assimilação e conversão - que dizia respeito também a Chamisso, embora não sendo judeu, por outras razões - atormentou no mais al to grau Rahel Varnhagen, que de bom grado dizia de si mesma, e por isso mesmo, que era uma "Schlemihl", uma eterna azarada, e isso apesar de todas as al egrias intelectuais que podia encontrar em seu salão, o mais importante da Alemanha entre 1790 e 1806, local onde se encontrava a maioria dos grandes nomes da época: os irmãos Humboldt, Friedrich von Schlegel, os filósofos Schleiermacher e Schelling, o príncipe Luís-Ferdinando da Prússia e seu primo príncipe Radziwill, Jean-Paul Brentano, os irmãos Ludwig e Friedrich Tieck, Fouqué, o naturalista Steffens, o juristaAdam Müller, o helenista FriedrichAugust Wolf. 
As questões que Rahel Varnhagen tenta responder pela arrenegação de sua judeidade, e Édouard Hitzig - o melhor amigo de Chamisso e seu primeiro biógrafo - pela assimilação "respeitável"(LAHNSTEIN, 1987, p.31), ${ }^{1}$ vão encontrar em Chamisso uma resposta: 0 envolvimento no exército prussiano estranhamente posto outra vez em questão pelas circunstâncias históricas. De fato, ser francês no exército prussiano na ocasião das guerras napoleônicas, começa a ficar cada vez mais difícil, ainda mais que em 7 de outubro de 1806 um decreto de Napoleão ameaça com o Conselho de Guerra todos os franceses que estejam servindo no exército da Prússia. Se em 1805 ele ainda escrevia ao seu amigo August Varnhagen, estando em campanha, na lama, debaixo de chuva: "Nada de povo nem de pátria, devemos seguir completamente sós" (idem), no ano seguinte quando a fortal eza de Hameln - onde ele sofreu o cerco dos franceses se rende sem combater - porque a Prússia tinha sido derrotada em Jena e Auerstedt - ele escreve: “U ma nova vergonha se prendeu ao nome alemão, e se tornou a ignomínia: a cidade se rendeu (...) Eu, o franco, fiquei paralisado como tal, e só podia chorar de raiva, chorar como uma mulher, porque deveríamos ter presenciado façanhas viris" (carta de 22 de novembro de 1806).

Ele então decide partir para a França, porque escreve a Fouqué: "Tenho o desejo de rever a França, vou me esconder lá por um momento, até que possa reencontrar meu lugar no meio de vocês, uma vez que sou alemão, de coração, mas um alemão livre, e serei sempre". Em dezembro de 1806, então, ele está em Paris, de onde ainda escreve a Varnhagen: "O deio a França, e a Alemanha não existe mais e ainda não existe". Essa Alemanha que não existe mais não é apenas a Alemanha política, desmembrada pelos franceses vitoriosos, mas também aquela Alemanha que, desde Goethe - e até 1870 - , seduziu tantos franceses; essaAlemanha ideal, cosmopolita, desinteressada, terra de todas as virtudes, mãe de todas as artes e de todas as ciências; essa Alemanha destinada a representar no mundo o papel de uma Hélade moderna. Ele volta então a Berlim, em busca de Berlim, mas é para constatar que de fato ela não existia mais. Berlim está então sob ocupação francesa. Todos os seus amigos alemães se tornaram patriotas, animados por um espírito de vingança, 0 cosmopolitismo era suspeito, em toda parte mostravam a ele um certo mau-humor crítico, criticavam-no por sua índole grosseira e taciturna, criticavam seus cachimbos e seus apetrechos de fumante. Os anos de 1808-1809 são difíceis para Chamisso. Em outubro de 1808, ele escreve a Fouqué:

“Minha vida, que deveria ter-se estabelecido e tomado forma, ao contrário, se extraviou na areia estéril. Boa parte daquilo que eu possuía se perdeu, foi destruído ou

${ }^{1}$ Este autor cita uma carta de Lea Salomon a seu noivo Abraham Mendelssohn, filho do filósofo e futuro pai do compositor. 
desapareceu, e por esse preço bem elevado adquiri muito pouco - uma boa medida de idade e uma pitada de extrato amargo de experiência. No final das contas o mundo se fechou para mim por todos os lados com tábuas pregadas, e não sei de onde partir nem para onde ir."

Refugia-se em casa do amigo Édouard Hitzig, onde passa dois anos na ociosidade e na angústia. Ele diz de si mesmo que é "o animal mais passivo do mundo".

Em 1810, está de novo na França, em Paris, que na ocasião era a capital da Europa. A França se estende dos Pirineus a Lübeck e de Nápoles aVarsóvia. Numa carta a sua irmã Rosa-Maria, ele escreve: "Vive-se muito bem à maneira alemã aqui em Paris". De fato, ele freqüenta a colônia alemã de Paris "porque em parte alguma fui mais pesadamente alemão" do que na França, diz ao amigo Fouqué. Aí ele encontra Alexander von Humboldt que o fascina com a descoberta da "fisionomia estrangeira da criação que nos é desconhecida", tem um romance com Helmina von Chezy - a Minna de Peter Schlemihl - "nascida von Klenke, outrora von Taster", que "tem dois filhos e outros tantos maridos". É um período de grande liberdade sexual: os românticos militavam pelo amor livre e pela emancipação das mulheres, e mesmo não sendo um adepto fervoroso dessa emancipação, Chamisso soube tirar partido dela na ocasião.

É nesse momento também que ele encontra Madame de Staël, a mesma que Napoleão, após tê-la exilado uma primeira vez, autorizou-a a instalar-se no castelo de Chaumont, onde Chamisso passa um longo período antes de segui-la na Suíça. Ali, após a publicação de seu livro Del'Allemagne, ela se vê outra vez proibida de residir na França. Em Chaumont, Chamisso está em boa companhia: háWilhelm Schlegel, Juliette Récamier, Mathieu de Montmorency, há artistas escandinavos, pintores italianos, homens de letras de todas as línguas. Para divertir as noitadas, Madame de Staël imaginara uma brincadeira que se chamava "o pequeno correio": todos se sentavam à volta de uma mesa, e aqueles que estavam defronte um do outro trocavam mensagens em tiras de papel dobradas, que podiam tratar de amor, de política, filosofia, literatura. Chamisso conservou a vida inteira, no meio de seus papéis, essas mensagens, dentre as quais uma conversa que teve com Madame de Staël sobre a pátria. Eis o que Chamisso escreveu:

"Minha pátria. Sou francês naAlemanha e alemão na França, católico entre os protestantes, protestante entre os católicos, filósofo entre os religiosos e carola entre as pessoas sem preconceitos; homem do mundo entre os sábios, e pedante no mundo, jacobino entre os aristocratas, e entre os democratas um nobre, um homem do Antigo Regime, etc. Em parte alguma sou apresentável, em toda parte sou estrangeiro eu gostaria de abarcar tudo, e tudo me escapa. Sou infeliz... U ma vez que esta noite o 
lugar ainda não foi tomado, permita que eu vá me atirar de cabeça no rio..." (CHAMISSO, 1814, p.53)

Após uma rápida permanência em Vendée, na casa do prefeito Barande, Chamisso reencontra Madame de Staël, exilada na Suíça por ordem do Imperador. Aí, el e começa, por ocasião de grandes passeios a pé, a se interessar pela flora suíça - ele se lembra da célebre frase deAlbrecht von Haller, naturalista originário de Berna: "A Suíça éo jardim botânico da Europa". Assim, compõe um herbário com mais de mil espécies e escreve ao seu amigo Hitzig: "Atualmente, sou meu próprio mestre, sem levar ninguém em consideração" (carta de 24 de maio de 1812). Entretanto, ele ainda não pode deixar Madame de Staël, por quem tem sentimentos complexos - os quais exprime em um dos raros poemas que escreveu em francês "À Corinne", que se inicia assim: "Conheci a Grécia, e volto à terra dos Citas".

Seu desejo de partir, de voltar para a Alemanha é sempre grande, mas, como escreve a Hitzig: “Cada vez que pareço ter a intenção de calçar as botas de sete léguas, a feiticeira me retém por meio de artimanhas e pela natureza, e faço sua vontade, uma vez que ela tem o poder" (idem). Entretanto, sua decisão amadurece, suas hesitações desaparecem: "Sou o ol har direto de meus olhos - eis aí a minha ética, a minha teosofia, a minha filosofia de hoje em diante". Era assim que ele caminhava:

"U ma velha kurtka polonesa, manchada e puída [...], uma grande caixa verde presa a uma correia de couro, um cachimbo curto na boca [...] maltratado, além disso, pelo suor e pela poeira, muitas vezes trazendo na mão um lenço abarrotado de ervas, ao encontro dos elegantes passeadores dominicais." [testemunho de Dietrich von Schlechtendal]

Em agosto de 1812, está de volta à Alemanha, onde se inscreve na U niversidade de Berlim, recentemente fundada, para estudar medicina e ciências naturais. Escreve ao amigo Fouqué: "Quero abraçar mais ou menos todas as ciências da natureza (...) Quero me apropriar da ciência pela observação e pela experiência, pelas coleções e comparações". Esse interesse pelas ciências da natureza e pela vida em todas suas manifestações era compartilhado por todos os seus contemporâneos, numa época em que as descobertas não paravam de se acumular em todos os domínios, transformando dessa maneira a idéia que as pessoas faziam da natureza, da qual antes era apenas vista na superfície, aparentemente monótona e uniforme. Essas descobertas - as de Volta e Galvani, de Lavoisier e Cavendish, de Cuvier e John Brown - revelaram aos olhos fascinados das pessoas cultas que 
"a riqueza da natureza ultrapassava tudo aquilo que a imaginação humana era capaz de conceber, que as explicações com que até então as pessoas tinham se contentado não valiam mais, e que era preciso procurar novas explicações, a menos que se quisesse ficar restrito à simples constatação dos fatos". (JANKELEVITCH, 1945, p.15)

A ciência moderna e a psicanálise são herdeiras desse movimento de observação dos fenômenos, e da busca de novas teorizações capazes de dar conta deles.

"A estranha história de Peter Schlemihl" foi escrita nessa ocasião, no verão de 1813, e publicada no ano seguinte. No prefácio da edição francesa de 1838, Chamisso conta como teria conhecido Schlemihl, e como este teria Ihe posto nas mãos seu manuscrito:

"Conheci Peter Schlemihl em Berlim em 1804, era um rapaz grandalhão e sem graça, sem ser desajeitado, inerte sem ser preguiçoso, mais freqüentemente fechado em si mesmo sem parecer inquietar-se com aquilo que se passava à sua volta, inofensivo mas sem consideração pelas conveniências, e sempre vestido com uma velha kurtka preta puída, que fizera com que dissessem dele que deveria se sentir feliz se sua alma compartilhasse a metade da imortalidade de seu casaco. Habitualmente ele era alvo dos sarcasmos dos nossos amigos; eu, entretanto, me afeiçoei a ele; diversos traços de semelhança estabeleceram uma ligação mútua entre nós. Em 1813 eu estava vivendo no campo, perto de Berlim (...) quando certa manhã nevoenta de outono, tendo ido dormir tarde, ao acordar fiquei sabendo que um homem de barbas compridas, vestindo uma velha kurtka preta puída e com pantufas por cima das botas, tinha perguntado por mim e deixado um embrulho dirigido a mim. Esse embrulho continha o manuscrito autógrafo da história maravilhosa de Peter Schlemihl." (Prefácio à edição francesa de 1838, Schrag, Paris)

É isso também o que ele escreve aos seus amigos Hitzig e Fouqué, ao enviarIhes o manuscrito. Aliás, Fouqué respondeu chamando Chamisso de "Meu caro Schlemihl". Contudo, ao mesmo tempo que é desmentida, a ficção de um Schlemihl real é mantida para divertir: eles têm o mesmo cachorrinho que se chama Fígaro, o mesmo empregado que se chama Bendel, amam as mesmas mulheres: Fanny (Hertz) e Minna (Helmina von Chezy), etc. E - algo que 0 próprio autor não podia prever por completo - têm o mesmo destino.

De fato, no ano seguinte, Chamisso escreve a seu amigo Louis de La Foye como Schlemihl podia ter feito após encontrar seu caminho: "Não tenho outra pátria, não posso ter outra, senão a república dos sábios, onde tenho a intenção de me estabelecer, humildemente e em silêncio, a fim de usufruir inocentemente a minha pequena liberdade." 0 desejo de conhecer o mundo, o desejo de viajar, se despertam nele de maneira viva, e quando em 1815 Ihe é oferecido tomar 
parte em uma viagem em volta do mundo como naturalista, ele aceita sem hesitar. Trata-se de uma expedição russa que tinha por objetivo encontrar uma passagem pelo Mar do Norte até o Pacífico. Chamisso tinha 35 anos de idade e partiu para explorar o mundo como geógrafo, geólogo, meteorologista, botânico, zoólogo, etnógrafo e lingüista. É nesses domínios que ele vai dar o melhor de si mesmo durante essa viagem que durou três anos, e que vai publicar e ficar famoso na volta. No Mar de Behring existe até hoje uma Ilha Chamisso.

Quanto mais se afasta, mais fica claro para ele seu apego à Alemanha. Em 1816 escreve do Chile ao amigo Hitzig, em 25 de fevereiro: "Graças a ti Berlim tornou-se para mim a terra dos meus pais e o umbigo do meu universo, de onde parti para executar o meu périplo, para voltar e aí estender meus ossos cansados para uma rápida refeição, quando chegar a hora, se Deus quiser." E voltando ao solo alemão, em 17 de outubro de 1818, eis o que ele escreve:

"Profundamente emocionado em sua alma, o viajante

Chega em casa, vindo de terras estrangeiras,

Apóia seu bastão, cai de joelhos

E molha teu regaço com lágrimas silenciosas,

Ó pátria alemã! - Por tanto amor,

Não Ihe recuses este pedido:

Quando seus olhos cansados se fecharem,

Permite que ele encontre aí a pedra

Debaixo da qual esconderá sua cabeça para dormir."

Na volta, Chamisso publica um artigo sobre a reprodução de uma espécie de pequenos moluscos marinhos, o que lhe vale o título de Doutor Honorário da Faculdade de Berlim. É nomeado Conservador do Herbário Real de Berlim, e em seguida Diretor do Jardim Botânico.

Torna-se célebre como navegador, naturalista e poeta. Em 1978, o Dictionary of Scientific Biography (Nova York, 1978) comparava seus trabalhos aos de Darwin, pela importância que lhe atribui a propósito da exploração - a primeira - das costas do Pacífico, e por sua hipótese da colonização das ilhas pelos vegetais, graças às sementes e aos frutos levados pelas correntes de superfície. Ele escreve a Louis de La Foye: "Aquilo que desejamos na juventude, temos em plenitude na maturidade, creio que sou um poeta da Alemanha" (maio de 1827). E quatro anos depois:

"O povo canta as minhas canções, estas são cantadas nos salões, os compositores ficam loucos por elas, os jovens as declamam nas escolas, meu retrato é colocado depois do de Goethe, Tieck e Schlegel, no quarto lugar da série dos poetas alemães 
contemporâneos, e as lindas mocinhas apertam a minha mão fervorosamente!... Quem haveria de imaginar tudo isso no nosso tempo de meninos!"

Em 1819, casa-se com uma jovem de 17 anos (ele tem 37) , Antonie Piaste, da qual diz que parecer-se "ao mesmo tempo com aVirgem e com o Menino". Eles irão ter sete filhos. Quando nasce o primeiro, Ernst Ludwig Deodatus, ele escreve a La Foye: "De acordo com o costume do país, eu o fiz batizar na religião protestante." E numa carta em versos dirigida a Fouqué, escreve:

“... Sim, amigo! Schlemihl

Não está mais privado de sua sombra, ele a tem ao triplo.

Primeiro a sombra de nossa águia prussiana

Que estende suas asas sobre ele, a fim de

Que ele encontre no presente o repouso e a paz

Na casa e no lar que o Rei

Outorgou-Ihe com uma boa pensão.

Em segundo lugar,

A sombra dessas árvores velhas e nobres

Que enfeitam o jardim chamado Botânico

Aqui, e não simplesmente 'pequeno Éden',

Do qual ele foi eleito guardião, príncipe das flores.

A terceira sombra, enfim, e a mais bonita

Votada a ele para nunca mais o deixar,

Seu anjo no presente, como há

Sempre um anjo perto de nós

Antonie - isso te diz o suficiente."

A história poderia parar aqui, e seria uma história bonita que termina bem, se não houvesse em seguida dois elementos em conexão com o que precede. 0 primeiro é uma viagem a Hamburgo, na família Hertz, uma das casas judaicas que ele freqüentava havia muito tempo. A bela Fanny de Peter Schlemihl é a Fanny Hertz, mulher de um dos Hertz, amigo de Chamisso e banqueiro em Hamburgo. Não é a Fanny que ele freqüenta por ocasião dessa viagem, mas sim a Marianne, a linda e vivaz dona de casa, que o recebe tão calorosamente que no ano seguinte vai nascer na família Hertz um menino, Wilhelm Hertz - que mais tarde vai se tornar livreiro e editor, amigo e editor deThéodore Fontane - ao mesmo tempo em que nascia, na família Chamisso, um menino, Max von Chamisso, ambos filhos de Adelbert. Esse nascimento ilegítimo não causou escândalo na família Hertz: foi mantido em segredo, mas ao mesmo tempo foi suficientemente transmitido de geração a geração para que, já no Terceiro Reich, uma descendente de 
Wilhelm Hertz conseguisse salvar sua vida provando que seu ancestral era filho de Chamisso. Mas as coisas não transcorrem de igual modo na família de Chamisso: dez dias após o nascimento deW ilhelm, a casa de Chamisso pega fogo. Ele escreve esta estranha frase ao amigo De La Foye: "Inflamar-se é um prazer, mas ser incendiada é a coisa mais aborrecida do mundo." Durante cinco anos ele não terá filho com sua mulher, mas, em seguida, têm os outros cinco. Durante este período ele, o viajante infatigável, não viaja mais. Conta-se também que por ocasião de uma noitada literária em seu salão, quando um amigo poeta lia um poema de amor, Antonie von Chamisso teria se levantado e saído da sala exclamando: "Não compreendo que se possa atribuir tanta importância ao amor!" Por fim, em 1826, ele está de novo na França, para recuperar a importância que Ihe cabia por direito na reparação concedida à sua família pelos prejuízos sofridos durante a Revolução. Ele escreve a Antonie, mas o tom das cartas mudou: não há mais a "minha estrela da manhã" , o "meu doce anjo". É:

"Não te esqueças das rosas. Não te esqueças do alfabeto (isto é, de ensinar o alfabeto às crianças), não te esqueças de pôr na minha janela a comida dos passarinhos, não te esqueças de cuidar das flores que plantei. Vou voltar para ti do mesmo modo como estava quando te deixei; trata de fazer com que eu também encontre tudo aí como estava quando parti."

O segundo elemento são os poemas: alguns são simples, cheios de alegria e de sentimento, como "Frauenliebe und Leben", musicados por Robert Schumann. Mas em muitos outros acontecem coisas horríveis, há uma busca daquilo que é anormal, um gosto pelo que é macabro, que fez Thomas Mann dizer que em Chamisso havia "uma oposição grosseira e quase patológica entre a ternura de um silfo e uma verdadeira necessidade de objetos fortes e mesmo horrendos". Assim, o poema "Sala y Gómez", um dos mais famosos, escrito 13 anos após o regresso de sua viagem em volta do mundo, durante a qual ele vislumbrou de longe o recife de Sala y Gómez, perdido entre céu e mar, habitado por aves marinhas, e do qual ele dizia em Remarques et idées:

“Há quem garanta que encontrou perto de Sala y Gómez os vestígios de um barco naufragado; nós o procuramos em vão. A gente estremece imaginando a possibilidade de que um ser humano tenha sido abandonado aí; porque os ovos das aves marinhas apenas teriam sido suficientes para prolongar sua miserável vida perdida (...) em cima desse rochedo nu, queimado pelo sol.

O poema imagina os pensamentos desse náufrago, seus sonhos que: 
“...elevam à nossa volta sua vigilância assustadora

E pronunciam palavras que provocam a loucura

Para trás! Para trás! Quem vos deu tamanho poder?

Por que agitas tuas madeixas ao vento?

Eu te conheço, menino impetuoso, selvagem,

Eu te olho e meu coração pára de bater.

Tu és aquele que eu fui quando me atirei na vida, Impelido por esperanças doidas, há tanto tempo,

E eu sou tu, a imagem erigida sobre tua sepultura.

Que é que ainda falas de beleza, de bondade, de verdade,

De amor e de ódio? Insensato!

Olha! Eu sou aquele que teus sonhos foram.

E queres conduzir também a ela à lembrança?

Deixa-me, mulher, já renunciei há muito tempo [...].

Não dirijas para mim esses olhares doces!

A luz de teus olhos e o som da tua voz

A morte já os anulou.

Teu crânio vazio e putrefato não tem mais olhares

Prometendo tais felicidades divinas;

Não existe mais o mundo em que investi minha fé.

O tempo onipotente, eu sou o único

Que o tem, em cima deste rochedo deserto,

Na minha pavorosa solidão."

E eis a sua oração, quando ele vê chegar o socorro:

"Não permitais, Senhor, graças a quem eu consegui me dominar, $N$ ão permitais que um barco e homens alcancem este rochedo

Enquanto não se extinguir o derradeiro eco do meu lamento!

Deixai que eu morra aqui no silêncio e na Paz!

Para que me serviria nesta hora tardia

Passar, cadáver entre os cadáveres?

Eles todos dormem no frio do túmulo,

Aqueles que saudaram minha vinda a esta terra

E há muito tempo já se apagaram todos os vestígios de mim

Sofri, Senhor, e fiz penitência

Quanto a reaparecer como estrangeiro no país natal, ... não!" 
Ele morreu em 1838, provavelmente de câncer de pulmão, 15 meses após sua mulher, que morreu de tuberculose. Deixaram sete filhos, entre 16 e 3 anos de idade. Antes de morrer, Adalbert redigiu um testamento no qual escreveu:

"Eu não decido nada a propósito do futuro de meus filhos. 0 mundo em que vivi não é aquele para o qual fui educado, e para eles vai ser a mesma coisa. Meus filhos devem tornar-se capazes de só contarem consigo mesmos, em diferentes países e em diversas carreiras. A pai xão pelo trabalho é o bem mais seguro, e eles devem adquiri-la."

O testamento está assinado em francês: Louis Charles Adélaïde de Chamissot de Boncourt, e em alemão: Adel bert von Chamisso. Poderíamos dizer, com outro poeta de língua alemã, mas que escreveu também em francês - trata-se de Rilke, em Le livre de la paurreté et de la mort - que ele teve

“... sua própria morte

A morte resultante dessa vida em que encontrou

0 amor, um sentido e o desamparo".

A propósito da história de Peter Schlemihl, em 1814 ele tinha escrito a seu irmão uma carta para explicar-Ihe a significação do nome.

"É um nome hebraico que significa mais ou menos Gottlieb, Théophile ou 'amado de Deus'. Na linguagem comum dos judeus é assim que se designa aquele que é desajeitado, azarado, aquele para quem nada dá certo no mundo. Um Schlemihl quebra o dedo no bolso de seu paletó, cai de costas e fratura o nariz, e é sempre inoportuno".

Mais adiante, no prefácio da primeira edição francesa de 1821, ele apresenta as coisas de maneira diferente, invertendo a ordem dos fatores: "enfim, o nome Schlemihl passou para nós como um provérbio, para os judeus não é assim, eles não fizeram desse nome um termo irônico".

A história de Peter Schlemihl pelo mesmo ponto se aproxima e se afasta da de seu autor. Isso começa de maneira banal e realista: um rapaz pobre se apresenta na casa de um homem rico, Monsieur John, com uma carta de recomendação, e 0 encontra ocupado com outras pessoas. Ele se junta ao grupo e percebe que cada vez que alguém exprime um desejo, um homenzinho vestido de cinzento sai de seu bolso e apresenta o objeto desse desejo. Primeiro é um curativo, em seguida uma luneta, depois um tapete de mais de cem metros quadrados, depois uma barraca dessa mesma medida, com todos os seus apetrechos, por fim três cavalos arreados para montaria. Inquieto, Peter se afasta do grupo para, na curva do caminho, encontrar o homem de cinzento que Ihe diz o seguinte: "Durante 0 
curto instante que tive a felicidade de passar perto do senhor - permita-me dizer-lhe, senhor - diversas vezes contemplei realmente com indizível admiração a sombra tão linda, tão linda, que o senhor projeta quando está ao sol, com uma espécie de nobre desdém, sem prestar atenção a isso - sim, essa sombra maravilhosa que está aí aos seus pés. Perdoe-me fazer-Ihe uma proposta que sem dúvida é audaciosa. Será que Ihe causaria repulsa ceder a mim essa sombra?" (CHAMISSO, p.43).

Poderíamos dizer, com Freud, que essa demanda "apresenta a superestimação sexual chocante quetem sua origem no narcisismo originário da criança" (FREUD, 1914/ 1969, p.94). Enfim, qualquer que seja o estigma narcísico dessa intervenção, Peter Schlemihl não escuta nada disso, e quando o homem de cinzento menciona a bolsa inesgotável, dentre as oito maravilhas que lhe propõe em troca, Peter aceita, porque "isso bastara para que ele conseguisse se apossar de [seu] espírito". É nos olhos dos outros que ele vai perceber muito rapidamente aquilo que perdeu. E nessa noite, ao adormecer em cima do ouro tirado de sua bolsa, ele tem um sonho:

“Lá eu te vi num sonho [ele se dirige a Chamisso]; parecia que eu estava atrás da porta de vidro do teu gabinete, e que de lá eu te via sentado à mesa de trabalho, entre um esqueleto e um punhado de plantas secas; diante de ti estavam abertos o $\mathrm{H}$ aller, $\mathrm{O}$ Humboldt, e o Lineu, em cima do teu sofá havia um volume de Goethe e' 0 anel mágico'; meus olhos ficaram muito tempo fixos em cima de ti, em cima de cada objeto que havia no quarto, depois novamente em cima de ti, mas tu não te mexias, não respiravas, estavas morto." (CHAMISSO, p.53)

Em A interpretação dos sonhos Freud diz que

"os sonhos sobre os mortos amados propõem problemas difíceis à interpretação, e nem sempre chegamos a resolvê-los de maneira satisfatória. Podemos procurar a razão disso na ambivalência afetiva em relação ao morto. É habitual que nesses sonhos o morto a princípio seja tratado como estando vivo, e que depois de repente se considere que está morto e que, na seqüência, ele continue vivo. Cheguei à conclusão de que essas al ternâncias de vida e de morte representam a indiferença do sonhador ('para mim tanto faz que esteja vivo ou morto'). Bem entendido, essa indiferença não é real, é desejada; destina-se a disfarçar as atitudes afetivas do sonhador que com freqüência são contraditórias; dessa maneira ela é a figuração em sonho, de sua ambivalência." (FREUD, 1900/ 1980, p.367)

Schlemihl termina por sair da cidade em companhia de seu fiel empregado Bendel e alguns outros dentre os quais o patife do Rascal que espalha o boato de 
que Schlemihl é o próprio rei, viajando disfarçado. "Fiquei envaidecido, mesmo nessas condições, de ter sido tomado pelo soberano reverenciado." Freud diz que há, diante da criança,

"uma tendência a suspender todas as aquisições culturais cujo reconhecimento astuciosamente se conseguiu arrancar de seu próprio narcisismo, e a renovar em nome dela a reivindicação de privilégios abandonados há muito tempo. Doença, morte, renúncia à fruição, restrições à sua própria vontade, não vão valer para a criança, e as leis da natureza e as da sociedade vão parar diante dela, que realmente será mais uma vez o centro e a essência da criação. His M ajesty the Baby, como outrora nos imaginávamos ser." (FREUD, 1914/ 1969, p.96)

Em companhia de seus dois duplos, o bom e o mau, Schlemihl vai tentar organizar sua nova vida. Após ter deixado uma mulher (Fanny) em cujos olhos lera o horror ante a ausência da sombra, ele tenta casar-se com outra (Minna) sem chegar a isso. Minna representa inteiramente um ideal sexual: no meio de um coro de moças de rara beleza, ela "eclipsava as outras como o sol eclipsa os astros da noite", e graças a ela "a majestade, a inocência e a graça, unidas à beleza", reinam.

Freud diz que

"Aquele que possui a qualidade eminente que falta ao Eu para atingir o ideal, é amado. Um expediente assim tem importância particular para o neurótico que, em função de seus investimentos objetais excessivos, fica empobrecido em seu Eu (...). Após ter desperdiçado sua libido sobre os objetos, ele busca então um caminho de volta ao narcisismo, escolhendo para si mesmo, segundo o tipo narcísico, um ideal sexual que possua as perfeições que Ihe parecem inatingíveis. De fato, ele não pode acreditar em outro mecanismo de cura, e traz à maior parte do tempo para o tratamento sua expectativa relativa a esse mecanismo, e dirige essa expectativa à pessoa do médico que cuida dele. Esse plano de cura esbarra natural mente na incapacidade de amar do doente, conseqüência de seus extensos recalcamentos." (idem, p.105)

Mas Peter Schlemihl não tem analista - como Chamisso também não - e quaisquer que sejam os esforços de seu duplo bom, o mau desfaz todos os seus planos e termina casando-se com Minna, no mesmo momento em que o diabólico homem de cinzento Ihe propõe uma nova transação: vender sua alma, em troca de sua sombra. Na hora de assinar, Schlemihl desmaia - o Eu não é senhor em sua própria casa - 0 sujeito só pode aparecer nesses rápidos momentos de ausência: a cabeça que gira, na primeira negociação, o desmaio por ocasião da segunda, e a passagem ao ato na terceira. 
Ao despertar, segue-se um episódio dissociativo durante o qual as diferentes partes da personalidade agem de maneiras autônomas, contraditórias, independentemente umas das outras: Rascal casa-se com Minna; Bendel, dominado pelo desejo de vingar seu patrão, acaba por seguir o homem de cinzento; este aparece sob formas diversas, sem nunca ser reconhecido de imediato por Schlemihl que persegue uma sombra sem dono pelo matagal. Isso termina com uma corrida louca através de bosques e planícies. "Um suor de angústia escorria de minha testa, meu peito era rasgado por gemidos fundos, a demência rosnava dentro de mim" - diz Schlemihl, e Chamisso escreve.

Em seu estudo sobre o "Duplo" publicado em 1914, e que Freud apreciou fez uma resenha de quase uma página em "O estranho" - Otto Rank fala dessa passagem dizendo: "Essas analogias demonstram que a sombra e a imagem representam aqui um Eu que se torna independente". Mas não foi nessas considerações psiquiátricas banais que pensei a esse propósito, mas sim em Lacan, dizendo que "é nas rupturas depressivas dos revezes vividos da inferioridade" que o Eu engendra

"as negações mortais que o paral isam em seu formalismo. 'Eu não sou nada disso que me acontece. Tu não és nada disso que tem valor'. Assim também se confundem os dois momentos, um em que o próprio sujeito se nega e um em que culpa o outro, e descobrimos aí essa estrutura paranóica do Eu (...). É o próprio delírio da bela alma misantrópica, lançando sobre o mundo a desordem que compõe seu ser." (LACAN, 1966, p.114)

Essa fuga desvairada inaugura um período de vida errante em companhia do homem de cinzento que se mostra de uma complacência extraordinária, de uma habilidade e uma destreza infinitas, "o verdadeiro modelo do criado de quarto para um homem rico", porém - condensação dos dois duplos precedentes - ele não esgota argumentos e comentários, convencido de que Schlemihl acabaria por assinar. Essa situação conflituosa dura até o momento em que, não podendo mais persistir nesse estado de guerra contra si mesmo, Schlemihl, tomado de horror, termina por atirar a bolsa no abismo junto ao qual eles estavam sentados. 0 homem de cinzento desaparece, Schlemihl se vê sozinho, aliviado, adormece e sonha.

"Num sonho delicioso, vi uma dança alegre entrelaçar imagens graciosas. Minna passava, muito leve, diante de mim, com uma coroa de flores nos cabelos, e eu the dirigia um sorriso amável. 0 virtuoso Bendel também estava coroado de flores e, passando, me fazia uma saudação de amizade. Ainda muitas outras pessoas me apareceram, inclusive tu, Chamisso, creio eu, longe, na multidão; uma luz viva brilhava e, no entanto, ninguém tinha sombra; a coisa mais estranha é que isso não causava 
espanto. Havia flores e cantos, amor e alegria debaixo dos bosques de palmeiras. Eu não podia parar nem explicar para mim mesmo essas figuras móveis e graciosas que um sopro bastaria para apagar, mas sei que esse sonho me encantava e eu temia acordar; de fato, eu já estava acordado e ainda mantinha os olhos fechados para conservar presentes na minha al ma por mais tempo essas visões fugidias."

Freud diz que

"é possível compreender que os objetos preferidos dos homens, seus ideais, decorram das mesmas percepções e experiências que os objetos dos quais eles têm mais horror; na origem eles só se distinguem uns dos outros por modificações ínfimas. Pode mesmo ocorrer ( ...) que o representante pulsional original tenha sido dividido em duas partes, uma das quais sofreu o recalcamento, enquanto a restante, precisamente por causa dessa íntima conexão, conheceu a idealização." (FREUD, 1915a/ 1968, p.52)

A relação entre recal camento e formação de ideal era apresentada em "Sobre o narcisismo: uma introdução", da maneira seguinte:

"As mesmas impressões, experiências, impulsos, moções de desejo a que este homem dá livre curso nele, ou que pelo menos elabora conscientemente, são repelidas por aquele outro com a máxima indignação (...). Podemos dizer que um estabeleceu em si um ideal pelo qual mede seu Eu atual, enquanto no outro tal formação ideal está ausente".

E conclui: "Aquilo que ele projeta diante de si como seu ideal é o substituto do narcisismo perdido de sua infância; naquela época ele era seu próprio ideal" (FREUD, 1914/ 1969, p.98).

É nessa via que Schlemihl parece engajar-se quando, ao despertar, decide partir ao acaso, "deixando à sorte o cuidado de fazer dele aquilo que ele tinha projetado". Como suas botas estavam gastas, ele é obrigado a comprar um novo par, e rapidamente se dá conta de que se trata de botas de sete léguas. Ele percorre o mundo para cima e para baixo, "ora medindo suas altitudes, ou a temperatura de suas fontes e a temperatura do ar, ora observando animais, ora examinando plantas", e percebe que parte do mundo Ihe ficara proibida para sempre, desconhecida porque separada por extensões de oceano excessivamente vastas - a Austrália, a Tasmânia - justo a parte que Chamisso não visitará por ocasião de sua viagem em volta do mundo. "Eu me sentei enfim no promontório mais avançado de Lamboc e, com o rosto voltado para o sul e para o leste, chorei como diante da grade solidamente fechada de uma masmorra." 
Ele tem então um momento de insight:

"Caí de joelhos, num recolhimento sem palavras, e derramei lágrimas de gratidão, porque de repente meu futuro se levantava claramente diante de mim. Excluído da sociedade dos homens por meu erro primordial, como reparação eu estava sendo conduzido em direção à natureza, que sempre amara; a terra me era dada por medida como um rico jardim, o estudo para ser meu guia e minha força, a ciência para constituir o objetivo da minha vida. Não era uma resolução que eu tomasse. Eu desde então só fiz procurar realizar fielmente, com uma aplicação tranqüila, inflexível, contínua, o ideal que se apresentou então claro e completo à minha consciência, e minha satisfação interior sempre dependeu do acordo entre a realidade e esse ideal."

"O desenvolvimento do Eu", diz Freud, "consiste no afastamento do narcisismo primário, e engendra uma aspiração intensa a recuperar esse narcisismo. Esse afastamento se produz pelo recurso do deslocamento da libido em direção a um ideal do Eu imposto a partir do exterior, e a satisfação é alcançada pela realização desse ideal" (idem, p.104). E Lacan fala da "função pacificadora do ideal do Eu, a conexão de sua normatividade libidinal com a normatividade cultural, ligada desde a margem da história à imago do pai" (LACAN, 1948/ 1966, p.117).

Se nada sabemos sobre o pai de Schlemihl, se quase nada sabemos sobre o pai de Chamisso - só sabemos que ele pertencia a um outro mundo que não era aquele no qual seu filho viveu, um mundo perdido para este - sabemos que a Chamisso foi preciso encontrar pais espirituais para si mesmo - Haller, Humboldt e Lineu, para voltar ao primeiro sonho de Schlemihl - para poder encontrar 0 caminho que Ihe permitiu tornar-se pai por sua vez, e semelhante a eles. " "Meu pai estava sempre ausente", dizia um analisando, "eu não tive referências" nenhum "pai feliz" ${ }^{3}$ E um outro, o quinto de seis filhos, forçado a cuidar de si mesmo após o bacharelado, uma vez que seu pai não tinha a possibilidade de ajudá-lo: "Tive a impressão de ter nascido num orfanato." Pais ausentes, distantes, idealizados ou enfraquecidos, o pai, dizia Lacan em "O mito individual do neurótico":

“...o pai é sempre um pai carente, um pai humilhado por algum lado (...). Há sempre um desacordo extremamente nítido entre aquilo que é percebido pelo sujeito no plano do real, e sua função simbólica. É nesse afastamento que está aquilo que faz com que o complexo de Édipo tenha valor (...) patogênico." (LACAN, 1980, p.75)

${ }^{2}$ Há no original um jogo de palavras por homofonia: “...devenir pèreà son tour, et leur paire”. ( N. daT.)

3 Idem: "jen'ai pas eu de repères - ou pas'd'heureux père'”. (N. daT.) 
$E$, no entanto, alguma coisa teve que ser "incorporada" da presença ou da palavra dele, alguma coisa teve que ser transmitida para impelir "o sujeito a formar o ideal do Eu (...), foi justamente a influência crítica dos pais conforme é transmitida pela voz deles; ao longo do tempo vêm juntar-se aí os educadores, os professores e a tropa inumerável e indefinida de todas as outras pessoas do ambiente (os outros, a opinião pública)" (FREUD, 1914/ 1980, p.100). As palavras e os olhares dos outros é que impedem Schlemihl de usufruir tranqüilamente seu estado.

Falando das estruturas de desconhecimento e de objetivação sistemática que caracterizam a formação do Eu, Lacan cita Heráclito a propósito da libido narcísica negativa "que está ligada à integração de uma desordem orgânica original, deiscência vital constitutiva do homem que faz brilhar novamente a noção heraclitiana da Discórdia, tida pelo efésio como anterior à Harmonia" (LACAN, 1948/ 1966, p.116).

Dois fragmentos de Heráclito chegaram até nós a propósito dessa questão da discórdia, um deles por intermédio de Diogene Laërce, o outro por Orígenes. Eis aqui os fragmentos:

“...tudo se faz por oposição dos contrários e tudo corre como um rio. (...) Entre contrários há uma luta que resulta na Criação; é aquilo a que chamamos de guerra e discórdia; a outra, que resulta na exaltação das paixões, chama-se concórdia e paz." (LAERCE, 1965, p.165-166)

E Orígenes, "ContreCelse", VI, 42: "É preciso saber que o conflito é comum ou universal, que a discórdia é o direito, e que todas as coisas nascem e morrem conforme a discórdia e a necessidade" (LES PRÉSOCRATIQUES, p.164).

Poderíamos dizer, com Freud, que as três polaridades que governam a vida psíquica se prendem de maneira significativa de modo que o que é estrangeiro, o que é exterior, o objeto, o odiado, sejam idênticos no início, uma vez que "com a entrada do objeto no estádio do narcisismo primário, chegamos também ao aparecimento do ódio". É isso que perturba o estado narcísico originário e prepara a progressão, para retomar uma pequena nota de "Os instintos e suas vicissitudes". Esse ódio que gera o desenvolvimento, rejeitado com indignação ou sufocado antes de ter podido tornar-se consciente, pode retornar sob determinadas formas, uma das quais é o duplo perseguidor. Retorno estranhamente inquietante.

Freud cita Chamisso quatro vezes - em "O estranho", justamente.

"O caráter de estranheza inquietante só pode real mente vir a partir do fato de que o duplo é uma formação que pertence ao tempo originário ultrapassado da vida psí- 
quica, que todavia tinha então um sentido mais amável. 0 duplo tornou-se uma imagem de espanto da mesma maneira que os deuses se tornam demônios após o desmoronamento de sua religião." (FREUD, 1919/ 1985, p.238-139)

O espanto, a repulsa de Schlemihl em relação ao homem de cinzento, seu ódio, sua angústia, adquirem sentido se, no lugar do homem de cinzento, colocarmos o pai temido do qual se espera a castração. A imago do pai, aqui, aliás como no "Homem de areia", estaria cindida pela ambivalência em duas séries: a série dos pais bons (Chamisso, Bendel, Haller, Humboldt, Fouqué), e a série dos maus (Rascal, o homem de cinzento, Monsieur John). 0 desejo de morte a propósito do pai bom estaria assim representado pelo sonho em que Chamisso aparece morto, e pela morte do pai de Minna. 0 que também mostra que Schlemihl e Minna são um só - a Minna que leva a passividade ante o pai ao ponto de lhe responder "Que se faça de mim aquilo que meu pai quiser", poderia dessa maneira simbolizar a atitude feminina de Schlemihl em relação ao pai na sua infância inicial - e, portanto, a paixão repentina que ele experiencia em relação a ela é narcísica, e só pode torná-lo estrangeiro ao objeto de amor real. Schlemihl não pode salvar Minna do casamento com Rascal, como também não pode se dar a conhecer a ela quando a encontra em seguida, uma vez que "o rapaz fixado a seu pai pelo complexo de castração é incapaz de amar uma mulher" (idem, p.233) .

Se o final da história é mais feliz do que para Nathanael e para Hoffmann, se isso termina em trabalho científico e em criação literária para Schlemihl e para Chamisso, e numa vida de bom pai de família para este último - será que poderemos ver aí também uma "espécie de aceitação intelectual do recalcado", comparável àquela que se produz no tratamento? (FREUD, 1925/ 1985, p.136). Ou estará aí uma maneira de disfarçar a origem suspeita da obra e do pensamento? Os poemas macabros de Chamisso, esse resultado da sublimação no qual o sublime oscila no horror, a paternidade reconhecida/ não reconhecida a propósito deWilhelm Hertz representam falhas dessa aceitação, ou será a própria aceitação dessa "solidão de morte, dessa intimidade polar" - para retomar um outro poeta (DICKINSON, 1989, p.49) - " de uma alma que é admitida a si mesma" ? Será que o jogo com os nomesADELaïde DE Chamissot/ ADELbertVON Chamisso representa uma maneira de matar o pai, de instaurar a si mesmo como origem - Adelbert, no alemão arcaico quer dizer etimologicamente Adel = nobre e bert = célebre, renomado - ou então de se inscrever na linhagem de seus pais, adaptando-se à época e ao país?

Ou então de seguir esse outro substituto do pai que Julius Edouard Hitzig foi para Chamisso, que escreveu para ele: "Graças a ti Berlim tornou-se a terra de meus pais." Hitzig de fato também modificara seu nome. Ele provinha da família Itzig de Potsdam, a quem o rei Frederico o Grande tinha arrendado a função de 
cunhar suas moedas, para sete milhões de thalers - o rei precisava de dinheiro depois da Guerra dos Sete Anos - preço pesado demais para eles se compensarem com as moedas desvalorizadas, sobre as quais o Estado ainda ganhava dinheiro. Se na Prússia - e na Áustria também, como podemos ver em Freud "Itzig" é o personagem de muitas histórias de judeus em que é ridicularizado, é por causa desse negócio, pelo qual o rei era mais responsável do que o banqueiro. Edouard se converteu muito cedo e juntou um " $\mathrm{H}$ " ao seu nome, tão injuriado pela tradição popular. Mas há outras razões que explicariam sua presença na série dos pais para Chamisso. Foi em casa de Hitzig que ele sempre encontrou refúgio nos momentos de crise; em todas as circunstâncias Hitzig concedeu-Ihe o apoio moral, material ou mundano - 0 apoio necessário para ser nomeado naturalista da expedição em volta do mundo - e foi seu primeiro biógrafo, aquele a quem Chamisso escrevia em 1811: "Há um parentesco entre nós, tu és superior a mim, tens um coração para me amar e uma cabeça para pensar por nós dois. Sabes qual é o meu mais caro desejo para os meus dias de velhice? É apoiar minha cabana na tua casa." E de fato foi isso que aconteceu.

As duas casas eram vizinhas, Chamisso passava tardes inteiras em casa de Hitzig que não apenas corrigiu, enfeitou e editou os poemas do amigo, mas também teve singular participação na própria elaboração poética. Eis o que Hitzig conta acerca dessa colaboração: "Essa colaboração entre os dois amigos explica superficialmente aquilo que com tanta freqüência tem sido criticado em Chamisso, aquela busca deliberada daquilo que é anormal." Ele não procurava, isso era levado para ele, é verdade que só Ihe era levado porque seu amigo sabia que dessa maneira lhe agradaria... Essa troca poética de temas entre os dois amigos formava uma estranha colaboração. Passando diante das janelas de Hitzig, que morava no térreo, Chamisso batia para tirá-lo de sua mesa e de suas pastas, com estas palavras: "Pai Ede, me dá combustível, já queimei tudo." E então Hitzig contava o que sabia. "Pai Ede", que era jurista, procurador geral temido, encarregado da revisão do Código Penal e fundador de diversas revistas de direito criminal, contava histórias de crimes, ou então "acontecimentos do dia" veiculados pelos jornais "de todos os países onde ainda existe virtude e vício em estado puro". No entanto, há, ainda, outra maneira para Hitzig estar na posição de pai para Chamisso, além dessa de Ihe proporcionar o alimento espiritual necessário. Sua mulher muito linda e muito amada, que ele desposara fora do ambiente judaico, contra a opinião da família, morreu depois de dez anos de casamento, ao dar à luz seu oitavo filho, em maio de 1814. Sua amiga íntima Lotte Piaste veio instalar-se em casa de Hitzig para cuidar dos filhos dele. Lotte, solteira, tinha aos seus cuidados uma sobrinha órfã, Antonie, que portanto foi educada a partir dos 12 anos de idade na família de Hitzig, com os filhos dele, até 1819, quando desposou Chamisso. Desposar uma moça da casa 
do Pai, sua "sombra", permite fundar um lar e encontrar por fim o Heimat, seu país natal.

Para dar prosseguimento aos jogos literários, os jogos com as letras e os nomes, as iniciais dos dois prenomes do primogênito de Chamisso, Ernst Ludwig, retomam as iniciais de Hitzig (Edouard) e de Chamisso (Louis). Quanto aos outros filhos - afora MAx, o filho nascido na mesma ocasião em que nasceu 0 filho de MArianne - suas iniciais retomam ora uma inicial de Chamisso (o A), ora uma de Hitzig ( o H ou o J): Adelaïde, Johanna, Adolph, Hermann eAdelbert. 0 fato de Max ter as iniciais do nome da amante de seu pai representa uma confissão, um modo de assinar seu "crime", ou ainda uma traição muito mais profunda diante de Antonie, mais profunda do que ela pudesse imaginar: a dificuldade de escolher entre diversas mães o quanto a primeira também tinha sido falha.

Um paciente de origem chinesa, bem integrado, sentindo-se muito estrangeiro ante seu pai que não fala francês, sentindo-se marcadamente europeu entre os asiáticos, e sofrendo por ser remetido à sua origem chinesa pelos europeus, contou que os prenomes chineses se compõem de duas partes: uma que é um significante escolhido pelos pais para todas as crianças da mesma família ( "Joli" [bonito], por exemplo) e a outra que é individual para cada criança, e que lhe é atribuída em função das circunstâncias que envolveram seu nascimento: predições, sonhos, ano do nascimento, circunstâncias históricas ("Pedra", "Rio", "Nuvem", etc.). 0 que em chinês pode resultar em Chou En- lâ̂, En-yuan, En-hua. Mas ele, é claro, renunciou a tudo isso, casou-se com uma francesa, fala francês em casa, e deu a seus filhos prenomes franceses. Ele os chamou de Daniel, Damian e David.

A questão do pai me leva à questão da morte, porque quando o pai se divide em duas partes no real, diz Lacan,

“o quarto elemento é a morte. É, de fato, da morte imaginada, imaginária, que se trata na rel ação narcísica. É também a morte imaginária e imaginada que se introduz na dialética do drama edipiano, e é dela que se trata na formação do neurótico - e talvez, até certo ponto, em algo que ultrapassa muito a formação do neurótico, a saber, a atitude existencial do homem moderno." (LACAN, 1980, p.77-78)

Chamisso dizia de si mesmo que era um "homem do futuro". Talvez isso explique o sucesso de Peer Schlemihl.

Num dos ciclos poéticos extensamente corrigidos pelo "Pai Ede", Chamisso põe em cena a morte do poeta na guerra, o corpo levado em cima de uma padiola para sua mulher, e as palavras desta dirigidas ao filho deles: 
"Tu és o único filho dele

Herdeiro do nome que ele adquiriu para si mesmo

Deves um dia pretender à mesma nobreza." (grifo nosso)

A proximidade da morte, presente em toda a obra de Chamisso, nos poemas "cor-de-rosa" tanto quanto nos poemas "negros", representa o abandono narcísico voluntário daquele que se encontra ante o vazio desse vínculo a si mesmo que se enrola sobre ele próprio, daquele que gostaria de "abarcar tudo", e que vê tudo Ihe escapar, ou será que isso é o que se poderia chamar de um horizonte próximo ao da análise, dessa planície de mortos, onde os conflitos se aprofundam e se ordenam, e onde a vida é aceita sem ilusões? E o fato de que todas essas questões possam ser propostas é próprio da sobredeterminação psíquica, desse emaranhado de interações complexas demais para que possam ser separadas com facilidade, ou será essa a marca particular da estrutura narcísica?

“O sujeito dessa maneira tem sempre uma relação antecipada a sua própria realização, que o rejeita no plano de uma profunda insuficiência, e dá provas de que existe nele uma fenda, um rasgo original, um abandono voluntário (...). É nisso que em todas as relações imaginárias, o que se manifesta é uma experiência da morte." (DICKINSON, 1989, p.49)

Enquanto isso, poderíamos dizer com Freud que

"a pesquisa psicanalítica nos permite seguir em outros casos os destinos das pulsões libidinais, uma vez que estas, isoladas das pulsões do Eu, se encontram em oposição a elas; porém, no domínio do complexo de castração, permite-nos, pelo raciocínio, subir de volta a uma época e a uma situação psíquica em que os dois tipos de pulsões ainda agiam em uníssono, e se apresentavam como interesses narcísicos numa mistura indissociável." (FREUD, 1914/ 1969, p.97)

Ou então, com Lacan, poderíamos enfatizar o caráter irredutível da estrutura narcísica:

"é em todas as fases do indivíduo, em todos os graus de realização humana na pessoa, que encontramos novamente esse momento narcísico no sujeito, num antes em que ele deve assumir uma frustração libidinal, e um depois onde ele transcende a si mesmo numa sublimação normativa". (LACAN, 1966, p.119)

A propósito dessa história, a questão que se propõe parece-me ser a do parentesco entre o tratamento e a criação literária. De fato, a criação de Schlemihl 
teve efeitos comparáveis aos de um término de tratamento: dar de novo a possibilidade de trabalhar e usufruir a vida (idem).

"Vemos", diz Freud em "O inconsciente", "que aquilo que é rejeitado do Ics se torna consciente como formações substitutas ou sintomas; de maneira geral, isso ocorre depois que o inconsciente sofreu deformações consideráveis". E ele aproxima essa situação da do tratamento: "Nós impomos ao paciente que forme uma quantidade de rejeitos do Ics e, para fazê-lo, nós o obrigamos a superar as objeções que a censura opõe ao tornar conscientes essas formações pré-conscientes, e a vitória sobre essa censura abre para nós o caminho para a abolição do recalcamento" (FREUD, 1913/ 1953, p.103).

No ano seguinte, na Conferência XXIII, ele faz um paralelo entre o tornar conscientes as formações fantasísticas, "graus preliminares da formação do sonho e do sintoma", e o tornar conscientes formações fantasísticas na atividade sublimatória:

“... os profanos só retiram um prazer limitado das fontes da fantasia. 0 caráter implacável de seus recalcamentos os obriga a contentar-se com raros devaneios que ainda é preciso que se tornem conscientes. Mas o verdadeiro artista pode mais do que isso. De saída, ele sabe dar a seus devaneios uma forma tal que estes perdem qualquer caráter pessoal suscetível de desagradar os estranhos, e se tornam fonte de prazer para os outros. Ele sabe também enfeitá-los de maneira a dissimular inteiramente sua origem suspeita. Possui, além disso, o poder misterioso de moldar materiais dados até fazer deles a imagem fiel da representação existente em sua fantasia, e ligar a essa representação de sua fantasia inconsciente uma quantidade de prazer suficiente para mascarar ou suprimir - aufgehoben - pelo menos provisoriamente, os recalcamentos. Quando consegue realizar tudo isso, ele proporciona aos outros o meio de novamente obter alívio e consolo nas fontes da fruição, que se tornaram inacessíveis, de seu próprio inconsciente; 0 artista atrai para si o reconhecimento e a admiração dos outros e finalmente conquistou, por meio de sua fantasia, aquilo que anteriormente só existia em sua fantasia: honras, poder, e o amor das mulheres." (FREUD, 1916-17/ 1969, p.354-355)

Adquiriu para si mermo um nome.

Freud sempre esteve fascinado pelo conhecimento que os escritores e os poetas tinham do inconsciente, e procurou na literatura a confirmação de suas próprias descobertas. Em 1922, ele escreveu a Schnitzler, com quem manteve correspondência desde 1906:

"U ma questão me atormenta: por que em verdade, durante todos esses anos eu nunca procurei me aproximar do senhor e ter uma conversa com o senhor (...) [se fre- 
qüentava seu irmão médico]. A resposta a essa questão implica uma confissão que me parece íntima demais. Penso que evitei o senhor por uma espécie de temor de encontrar o meu duplo. Não que eu tenha facilmente a tendência a me identificar com um outro, ou que tenha querido negligenciar a diferença que nos separa, mas ao merguIhar em suas esplêndidas criações eu sempre acreditei que encontraria aí, por trás da aparência poética, as hipóteses, os interesses e os resultados que sabia que eram os meus. 0 seu determinismo tanto quanto 0 seu ceticismo (...), a sua sensibilidade às verdades do inconsciente, à natureza pulsional do homem, a dissecção que o senhor fazia de nossas certezas culturais convencionais, a parada de seus pensamentos em cima da polaridade do amor e da morte, tudo isso despertava em mim um estranho sentimento de familiaridade... Assim, tive a impressão de que o senhor intuitivamente sabia - ou antes, sabia em seguida a uma sutil auto-observação - tudo aquilo que descobri com o auxílio de laborioso trabalho prático com outras pessoas. Sim, creio que no fundo de si mesmo o senhor é um investigador das profundezas psicológicas, tão honestamente imparcial e intrépido como ninguém nunca foi, e se 0 senhor não fosse assim, as suas capacidades artísticas, a sua arte da linguagem e seu poder criador teriam dado a si mesmos livre curso e teriam feito do senhor um escritor muito mais ao gosto da massa. Quanto a mim, prefiro o investigador. Mas perdoe-me se torno a cair na psicanálise, mas não sei fazer outra coisa. Só sei que a psicanálise não é um meio de se fazer amar." (JONES, 1969, p.500-501)

Basta pensarmos no ódio que colhemos da parte de determinados pais, quando uma criança em tratamento começa a melhorar.

A sutil auto-observação do escritor, como a auto-análise de Freud, como 0 tratamento, permitem, portanto, a aproximação à verdade do inconsciente, mesmo que "o nome'psicanálise' só se aplique aos procedimentos em que a intensidade da transferência é utilizada contra as resistências" (FREUD, 1913/ 1953, p.103). Como é que eles chegam a isso?

“U ma cooperação entre uma moção pré-consciente e uma moção inconsciente, mesmo que esta esteja intensamente recalcada, pode se produzir, se a situação for tal que a moção inconsciente possa agir no mesmo sentido que uma das tendências dominantes. Dessa vez o recal camento é abolido, a atividade recalcada é admitida à medida que reforça aquela a que o Eu se propõe. 0 inconsciente fica de acordo com o Eu por essa única constelação, sem que por outro lado coisa al guma seja modificada em seu recalcamento. Não se pode desconhecer o sucesso do Ics nessa cooperação; as tendências reforçadas se comportam de maneira bem diferente das tendências normais, tornam possível uma ação particularmente perfeita e mostram, a propósito das contradições, uma resistência semelhante à dos sintomas obsessivos, por exemplo." (FREUD, 1915b, p.108-109) 
Esta situação, que se encontra na criação literária, pode ser encontrada também no tratamento, em que o que é visado é exatamente aquilo que foi sepultado e se tornou inacessível pelo recal camento. E "é uma simples questão de técnica analítica determinar se vamos ter sucesso quanto a fazer aparecer completamente aquilo que foi ocultado" (FREUD, 1937, p.273). A transferência sobre 0 analista e sobre os ideais analíticos, como a concentração de libido sobre os objetos imaginários no artista, torna possível o reinvestimento desse "território intermediário da fantasia" que "goza do favor geral da humanidade" e "onde todos aqueles que são privados de alguma coisa vêm buscar compensação e consolo" (FREUD, 1916-17, p.354). Esse reinvestimento permite ao analisando reencontrar a lembrança escondida, mas nem sempre: "com muita freqüência não se tem sucesso quanto àquilo que o paciente se lembra do recalcado. Em troca, uma análise corretamente conduzida o convence firmemente da verdade da construção, o que, do ponto de vista terapêutico, tem o mesmo efeito de uma lembrança reencontrada" (idem, p.278). Reescreve-se a história. 0 "empuxo" do recalcado "para cima", portanto, é ativado pela construção analítica ou literária e, graças à transferência ou à fraqueza constitutiva que impede os recalcamentos extensos, permite preencher as lacunas da memória, vencer as resistências do recalcamento, reconstruir sua história, recuperar uma continuidade de ser.

0 analista, como o escritor, leva em conta as leis que regem a vida do inconsciente. Entretanto, ao contrário do analista, o escritor não precisa exprimi-las nem percebê-las de modo claro "graças à tolerância de sua inteligência, elas são incorporadas a suas criações" (FREUD, 1907, p.242).

0 analista, como o escritor, constrói sua "obra" com a mesma massa, o fundo das impressões e das recordações esquecidas, sejam elas "pessoais ou pertençam ao paciente, ao reescrever sua história". Por que vias, por que processos esse fundo se introduz na "obra", esta é uma simples questão de técnica literária ou analítica.

Recebido em 13/ 6/ 2005. Aprovado em 4/ 7/ 2005. 


\section{REFERÊNCIAS}

ARENDT, H. (1986) Rahe Varnhagen, Paris: Tierce.

CHAMISSO, A. von (1814) L'érange histoire de Peter Schlemihl, Paris: Schrag.

DICKINSON, E. (1989) "Il est une solitude", in Vivre avant l'évél, Paris: Artfuyen.

FONTANE, B. (1977)Die Marker und die Berliner, München: Deutscher Taschenbuch Verlag.

FREUD, S. (1900/ 1980) L'interpretation des rêves, Paris: PUF. . (1907) Délire et rêves dans la Gradiva de Jensen, Paris: Gallimard, NRF. . (1913/1953) "Le début du traitement", in La technique psychanalytique, Paris: PUF. . (1914/ 1969) "Pour introduire le narcissisme", in La vie sexuelle, Paris: PUF. . (1915a/ 1968) "Le refoulement", in Métapsychologie, Paris: Gallimard (Col. Idées). . (1915b/ 1968) "L'inconscient", Paris: Gallimard (Col. Idées). (1916-17/ 1969) Introduction à la psychanalyse, Paris: Petite bibliothèque Payot. . (1916-17) "Conférence XXIII", in Introduction à la psychanalyse, Paris: PUF. . (1919/ 1985) “L'inquiétante étrangeté", in L'inquiétante étrangeté et autres essais, Paris: Gallimard (Folio). PUF. . (1925/ 1985) "La négation", in Résultats, idées, problèmes, I, Paris: . (1937) "Constructions dans l'analyse", in Résultats, idées, problèmes, II, Paris: PUF.

JANKELEVITCH, S. (1945) F.W. Schelling, Paris: Aubier. JONES, E. (1969) La vie et l'oeuvre de S. Freud, III, Paris: PUF. LACAN, J. (1966) "L'agressivité en psychanalyse", in Écrits, Paris: Seuil. LAERCE, D. (1965) Vies, doctrines et sentences des philosophes illustres, II, Paris: Garnier Flammarion.

LAHNSTEIN, P. (1987) Adelbert von Chamisso, Paris: Flammarion. LES PRESOCRATIQUES, Paris: Gallimard (Pléiade) .

LORTHOLARY, B. (1992) Préface à L'étrange histoire de Peter Schlemihl, Paris: Gallimard.

RIEGEL, R. (1950) La vie d'un déraciné, Paris: Aubier.

Sabine Parmentier 49, rue de Chatenay 92160

Antony, França 